\title{
Effect of Corrosion Inhibitors on Concrete Pore Solution Composition and Corrosion Resistance
}

\author{
by M. O'Reilly, D. Darwin, J. Browning, L. Xing, C. E. Locke Jr., and Y. P. Virmani
}

\begin{abstract}
Three commercially available corrosion inhibitors-calcium nitrite, a solution of amines and esters, and an alkenyl-substituted succinic acid salt-are evaluated in conjunction with conventional reinforcement in concrete based on corrosion rate, metal loss, the critical chloride corrosion threshold (CCCT), pore solution analyses, and concrete compressive strength. All three inhibitors increase time to corrosion initiation and decrease corrosion rate, but are less effective in cracked concrete than in uncracked concrete. Of the three inhibitors, the alkenyl-substituted succinic acid salt results in the greatest decrease in corrosion rate, but exhibits the lowest CCCT-below that measured in concrete with no inhibitor. The compressive strengths of concretes containing the amine-ester inhibitor and the alkenyl-substituted succinic acid salt were $15 \%$ and $60 \%$ lower, respectively, than concrete without an inhibitor. For the latter inhibitor, pore solution analyses indicated elevated sulfate contents at 1 and 7 days, which may explain the low CCCT and strength. Paste containing the amine-ester inhibitor had an elevated sulfate content at 7 days.
\end{abstract}

Keywords: chlorides; corrosion; corrosion inhibitor; cracking; durability; pore solution; steel reinforcement.

\section{INTRODUCTION}

Chloride-induced corrosion of reinforcing steel in structures, such as bridges, has been a major concern for many years (Manning 1996; Koch et al. 2002). Chlorides from deicing salts or seawater can penetrate the concrete and build up over time until the concentration reaches a level sufficient to depassivate the steel. Once this occurs, the steel will begin corroding and eventually the volume of the corrosion products will be sufficient to crack and spall the concrete cover. The annual cost of this corrosion for bridge structures alone can be measured in billions of dollars (Koch et al. 2002).

Corrosion-inhibiting admixtures, both inorganic and organic, have been developed with the goal of delaying the onset of corrosion or slowing the rate of corrosion once the steel has been depassivated. These admixtures work by interfering with the corrosion reaction or by slowing the rate of chloride, oxygen, and moisture penetration by decreasing the permeability of the concrete. One inorganic corrosion inhibitor and two organic corrosion inhibitors were evaluated in this study with the goals of: 1) comparing their performance based on the quantity of chlorides required to initiate corrosion and the rate of corrosion after initiation in cracked as well as uncracked concrete; and 2) examining and explaining the negative impact of the two organic inhibitors on compressive strength.

Calcium nitrite $(\mathrm{CN})$ is an inorganic corrosion inhibitor that helps stabilize the passive layer on the steel surface. In addition to forming a passive layer, calcium nitrite also competes with chloride ions for ferrous ions, preventing the chlorides from initiating corrosion (Berke and Rosenberg 1989). Studies examining the effectiveness of calcium nitrite have yielded positive results, with reinforcement in concrete with calcium nitrite exhibiting a longer time to corrosion initiation and correspondingly higher chloride content in uncracked concrete (known as the critical chloride corrosion threshold) than reinforcement in concrete without calcium nitrite (Pyc et al. 1999; Bola and Newtson 2005; Xing et al. 2010). In addition to serving as a corrosion inhibitor, calcium nitrite acts as a set accelerator. To counteract this, calcium-nitrite-based inhibitors are often combined with a set retarder. No significant reductions in compressive strength have been observed for concrete with calcium nitrite.

The first organic inhibitor in this study is a water-based organic corrosion inhibitor composed of amines and esters (AE). This inhibitor protects steel by adsorption of the amines on the surface of the reinforcement, where they form a protective film. In addition, this inhibitor forms an insoluble salt, blocking the pores in concrete and decreasing permeability. Research involving AE has yielded mixed results. An analysis by Soylev and Richardson (2008) found that while it and other organic inhibitors delayed the onset of corrosion, there was no significant effect on corrosion rate in uncracked concrete; they, however, noted that other studies contradicted this finding (Nmai et al. 1992; Batis et al. 2003). Nmai et al. (1992) observed an approximately $10 \%$ reduction in strength for concrete containing this inhibitor compared to concrete with no inhibitor. No other significant adverse effects on material properties were observed.

The second organic inhibitor (disodium tetrapropenyl succinate) is a salt of alkenyl-substituted succinic acid (ASSA). The polar end of the molecule binds to the steel, possibly stabilizing the passive layer. The molecule also exhibits hydrophobic properties, decreasing the tendency for moisture to enter concrete (Wojakowski and Distlehorst 2009). Prior research has noted significant reductions in corrosion rate in both uncracked and cracked concrete (Goodwin et al. 2000; Civjan et al. 2003; Gong et al. 2006; Xing et al. 2010). In addition, these studies noted reductions in concrete compressive strength with the use of ASSA, with reductions of between 12 and 52\% compared to concrete without an inhibitor.

Each of the inhibitors evaluated in this study displays potentially undesirable effects on concrete properties not directly related to corrosion resistance-calcium nitrite acts as a set accelerator, while strength reductions have been observed with the organic inhibitors-and as

ACI Materials Journal, V. 110, No. 5, September-October 2013

MS No. M-2012-079.R1 received January 14, 2013, and reviewed under Institute publication policies. Copyright (C) 2013, American Concrete Institute. All rights reserved, including the making of copies unless permission is obtained from the copyright proprietors. Pertinent discussion including author's closure, if any, will be published in the July-August 2014 ACI Materials Journal if the discussion is received by April 1,2014. 
ACI member Matthew O'Reilly is an Assistant Professor of civil, environmental, and architectural engineering at the University of Kansas, Lawrence, KS. He received his $B S$ in mechanical engineering from the University of Rochester, Rochester, NY, and his $M S$ and $P h D$ in civil engineering from the University of Kansas.

ACI Past President David Darwin, FACI, is the Deane E. Ackers Distinguished Professor and Chair of the Department of Civil, Environmental and Architectural Engineering at the University of Kansas, Lawrence, $\mathrm{KS}$. He is a member of ACI Committees 130, Sustainability of Concrete; 222, Corrosion of Metals in Concrete; 224, Cracking; 318-B, Reinforcement and Development (Structural Concrete Building Code); and Joint ACI-ASCE Committees 408, Development and Splicing of Deformed Bars; 445, Shear and Torsion; and 446, Fracture Mechanics of Concrete.

JoAnn Browning, FACI, is a Professor of civil, environmental, and architectural engineering and an Associate Dean of Engineering at the University of Kansas. She is a member of the ACI Technical Activities Committee and ACI Committees 314, Simplified Design of Concrete Buildings; 318-D, Flexure and Axial Loads: Beams, Slabs, and Columns (Structural Concrete Building Code); 341, Earthquake-Resistant Concrete Bridges; 374, Performance-Based Seismic Design of Concrete Buildings: and Joint ACI-ASCE Committee 408, Development and Splicing of Deformed Bars.

Lihua Xing is a Structural Engineer with Archer Daniels Midland Company, Decatur $I L$. She received her BS in structural engineering from Lanzhou Jiaotong University, Lanzhou, Gansu, China; her MS in mathematics from Marquette University, Milwaukee, WI; and her PhD in civil engineering from the University of Kansas.

Carl E. Locke Jr. is Professor Emeritus of chemical and petroleum engineering and former Dean of Engineering at the University of Kansas. His research interests include corrosion of steel in concrete.

Y. Paul Virmani is the Corrosion Specialist in the Office of Infrastructure Research and Development of the Federal Highway Administration. His research interests include reinforced concrete, prestressed concrete, and cable-stayed bridges.

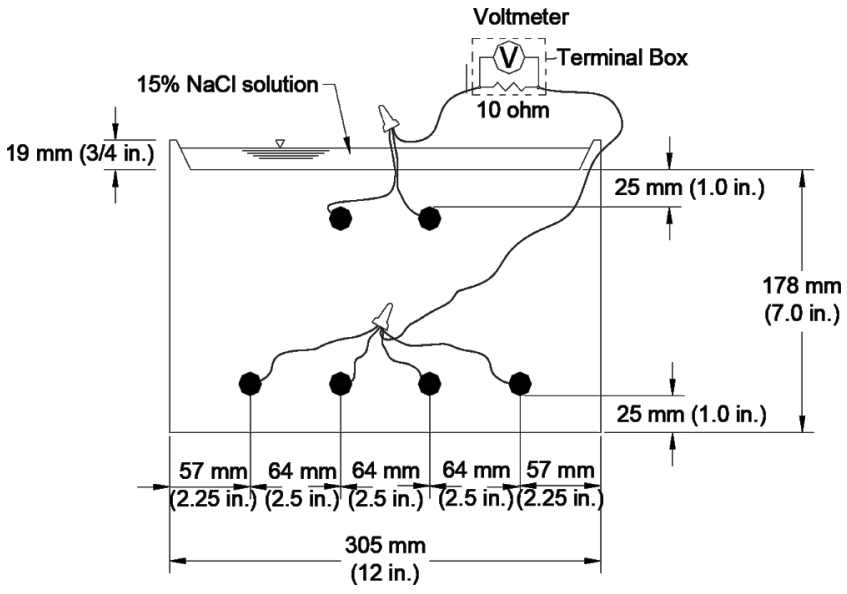

Fig. 1-Southern exposure specimen.

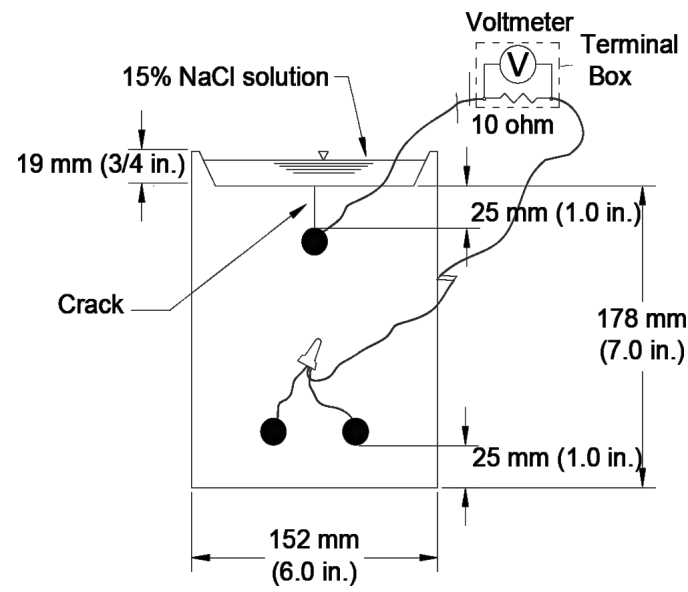

Fig. 2-Cracked beam specimen. demonstrated herein, ASSA appears to reduce the chloride corrosion threshold. Analyzing the pore solution of cement pastes containing these inhibitors can provide insight into their behavior, as is demonstrated in this study. Full details of the research are described in O'Reilly et al. (2011)

\section{RESEARCH SIGNIFICANCE}

The life expectancy of reinforced concrete structures subject to chlorides depends on the chloride content required for corrosion initiation and the corrosion rate of the reinforcement after initiation. The purpose of this research is to compare the performance of three widely used corrosion inhibitors on the critical chloride corrosion threshold (CCCT) and their effects on corrosion rate of reinforcing steel in cracked, as well as uncracked, concrete. Furthermore, an analysis of the concrete pore solution is performed to provide insight into the behavior of concrete containing these corrosion inhibitors and the negative effect of one of the inhibitors on the CCCT.

\section{Corrosion rate}

\section{EXPERIMENTAL WORK}

Specimens-The corrosion rate of conventional reinforcement in concrete without and with a corrosion inhibitor was measured in both uncracked and cracked concrete using southern exposure and cracked beam specimens, respectively. Southern exposure specimens (Fig. 1) are $305 \times 305 \times 178 \mathrm{~mm}(12 \times 12 \times 7$ in. $)$ concrete prisms with two mats of No. 16 (No. 5) conventional steel reinforcing bars, each with $25 \mathrm{~mm}$ (1 in.) clear cover. Bars in each mat are spaced at $64 \mathrm{~mm}$ (2.5 in.). The bars in the top and bottom mats are electrically connected via external wiring to a terminal box across a $10 \mathrm{ohm}$ resistor to allow for macrocell corrosion rate measurements. The specimens are cast in an inverted position. To allow for ponding of the salt solution, a $19 \mathrm{~mm}$ (0.75 in.) concrete dam is cast integrally with the specimen. Prior to testing, the upper surface of the specimen is sanded lightly to remove any laitance.

In the field, it is common for settlement cracks to form over reinforcement in bridge decks, providing chlorides with direct access to the reinforcing steel. A survey of state departments of transportation found that these transverse cracks have widths ranging from 0.05 to $0.65 \mathrm{~mm}$ (2 to 25 mils) (Krauss and Rogalla 1996). Cracked beam specimens (Fig. 2) are used to test the performance of inhibitors in cracked concrete, such as found on bridge decks. The specimens are half the width of the southern exposure specimens, with a single No. 16 (No. 5) bar in the top mat and two No. 16 (No. 5) bars in the bottom mat. A $0.3 \times 151 \mathrm{~mm}$ (12 mil x 6 in.) stainless steel shim is inserted into the mold centered on the top bar prior to casting. This shim is removed 12 hours after casting, creating a $151 \mathrm{~mm}$ (6 in.) long simulated crack in the concrete cover. Rodriguez and Hooton (2003) observed that for smooth- and rough-walled cracks ranging in width from 0.08 to $0.68 \mathrm{~mm}$ (3 to $27 \mathrm{mils}$ ), the rate of chloride diffusion is independent of crack width or roughness. The crack simulated using the shim is therefore typical of those found in bridge decks (Krauss and Rogalla 1996). The cracked beam test is performed in accordance with ASTM A955/A955M (2010).

The concrete mixture proportions for the southern exposure and cracked beam specimens are shown in Table 1. A water-cement ratio $(w / c)$ of 0.45 , typical of that used in low-cracking high-performance bridge decks (Darwin et 
Table 1-Mixture proportions for southern exposure, cracked beam, and corrosion initiation specimens

\begin{tabular}{|c|c|c|c|c|c|c|}
\hline Mixture & $\begin{array}{c}\text { Water, } \mathrm{kg} / \mathrm{m}^{3} \\
\left(\mathrm{lb} / \mathrm{yd}^{3}\right)\end{array}$ & $\begin{array}{c}\text { Cement, } \mathrm{kg} / \mathrm{m}^{3} \\
\left(\mathrm{lb} / \mathrm{yd}^{3}\right)\end{array}$ & $\begin{array}{c}\text { Coarse aggregate, } \mathrm{kg} / \mathrm{m}^{3} \\
\left(\mathrm{lb} / \mathrm{yd}^{3}\right)\end{array}$ & $\begin{array}{c}\text { Fine aggregate, } \mathrm{kg} / \mathrm{m}^{3} \\
\left(\mathrm{lb} / \mathrm{yd}^{3}\right)\end{array}$ & $\begin{array}{l}\text { Air-entraining agent, } \\
\mathrm{mL} / \mathrm{m}^{3}\left(\mathrm{oz} / \mathrm{yd}^{3}\right)\end{array}$ & $\begin{array}{c}\text { Inhibitor, } \mathrm{L} / \mathrm{m}^{3} \\
\left({\left.\text { gal. } / \mathrm{yd}^{3}\right)}^{2}\right.\end{array}$ \\
\hline Control & $160(269)$ & $355(598)$ & $880(1484)$ & $851(1435)$ & $90(2.33)$ & - \\
\hline $\mathrm{AE}$ & $156(262)$ & $355(598)$ & $880(1484)$ & $851(1435)$ & $300(7.74)$ & $5(1.01)$ \\
\hline ASSA & $154(259)$ & $355(598)$ & $880(1484)$ & $851(1435)$ & $35(1.18)$ & $7.6(1.54)$ \\
\hline
\end{tabular}

al. 2010), was used for all specimens. Specimens are wetcured for 3 days and air cured for 25 days prior to testing. The concrete properties, including the average compressive strength at 28 days for four $102 \times 204 \mathrm{~mm}(4 \times 8$ in.) cylinders cured in lime-saturated water, are shown in Table 2.

Test procedures and measurements-The southern exposure and cracked beam tests take 96 weeks. The tests alternate between two cycles for the duration of the test. On Day 1 of the first cycle, a $15 \% \mathrm{NaCl}$ solution is ponded on the surface of the specimens. The solution concentration provides for relatively rapid corrosion initiation (McDonald et al. 1998) and has been adopted in ASTM A955/A955M (2010) for the cracked beam test. The specimens are maintained at room temperature $\left(20 \pm 2^{\circ} \mathrm{C}\left[72 \pm 3^{\circ} \mathrm{F}\right]\right)$ and readings are taken on Day 4. The voltage drop across the $10 \mathrm{ohm}$ resistor is measured to determine the corrosion macrocell current. Dividing the measured current by the surface area of the test bar gives the average corrosion current density $i$ (traditionally expressed in $\mu \mathrm{A} / \mathrm{cm}^{2}$ ), which is used to determine corrosion rate $R$ (in $\mu \mathrm{m} / \mathrm{yr}$ or mils/yr) using Faraday's Law, written assuming that corrosion occurs uniformly over the surface area of the bar.

$$
R=k \frac{i a}{n F \rho}
$$

where $k$ is the conversion factor-315,360 A. $\mu \mathrm{m} \cdot \mathrm{s} /$ $(\mu \mathrm{A} \cdot \mathrm{cm} \cdot \mathrm{yr}) ; a$ is the atomic weight of the corroding metal, $\mathrm{g} / \mathrm{mol} ; n$ is the number of electrons lost per atom of metal oxidized; $F$ is Faraday's constant-96,485 Coulombs/equivalent; and $\rho$ is density of metal, $\mathrm{g} / \mathrm{cm}^{3}$.

For iron, $a=55.85 \mathrm{~g} / \mathrm{mol} ; n=2 ; \rho=7.87 \mathrm{~g} / \mathrm{cm}^{3}$; and Eq. (1) simplifies to $R=11.6 i \mathrm{in} \mu \mathrm{m} / \mathrm{yr}$ or $0.457 i$ in mils/ year. Corrosion loss is obtained by integrating the corrosion rate over time.

After measuring the voltage drop, the top and bottom mats are electrically disconnected via a switch on the terminal box and left disconnected for a minimum of 2 hours to allow the corrosion potentials to stabilize. The saturated state of the concrete and low cover minimize any error in potential readings due to resistance of the concrete. After taking the potentials, the top and bottom mats are reconnected via the switch on the terminal box to allow corrosion to continue. After the readings are complete, the salt solution is removed from the specimens and a heat tent is placed over the specimens to maintain a temperature of $38 \pm 2^{\circ} \mathrm{C}\left(100 \pm 3^{\circ} \mathrm{F}\right)$ for 3 days, completing one full week. The tent is removed and the cycle is repeated for 12 weeks. After 12 weeks of ponding and drying, the specimens are ponded at room temperature for 12 weeks with the $15 \% \mathrm{NaCl}$ solution and covered with plastic sheeting. Readings continue to be taken on a weekly basis, but the heat tent is not used. Deionized water is added as needed to maintain the level of the solu-
Table 2-Concrete properties

\begin{tabular}{c|c|c|c|c}
\hline Specimen & $\begin{array}{c}\text { Slump, mm } \\
\text { (in.) }\end{array}$ & Air, \% & $\begin{array}{c}\text { 28-day compressive } \\
\text { strength, MPa (psi) }\end{array}$ & $\begin{array}{c}\text { Coefficient } \\
\text { of variation }\end{array}$ \\
\hline Control & $55(2-1 / 4)$ & 5.25 & $35.8(5190)$ & 0.066 \\
\hline CN & $95(3-3 / 4)$ & 5.0 & $40.0(5800)$ & 0.091 \\
\hline AE & $50(2)$ & 4.0 & $30.4(4410)$ & 0.146 \\
\hline ASSA & $90(3-1 / 2)$ & 5.25 & $14.2(2060)$ & 0.136 \\
\hline
\end{tabular}

tion. After 12 weeks of continuous ponding, the specimens are again subjected to the weekly ponding and drying cycles. The two 12-week exposure regimes are repeated three more times for a total of 96 weeks.

\section{Critical chloride corrosion threshold}

Specimens-The test specimens for the corrosion initiation are identical to the cracked beam specimens with the exception that the stainless steel shim is not inserted into the formwork, leaving the concrete cover uncracked. All specimens are cast with conventional reinforcement. The concrete mixture proportions for the corrosion initiation beams are the same as for the southern exposure and cracked beam specimens.

Test procedure and measurements-The curing and test procedures for the corrosion initiation beams are the same as for southern exposure and cracked beam specimens with the exception of test duration (Darwin et al. 2009, 2011). Corrosion initiation beams are removed from testing at the onset of corrosion, defined as an increase in corrosion rate to above $0.3 \mu \mathrm{m} / \mathrm{yr}(0.01 \mathrm{mils} / \mathrm{yr})$ and a drop in corrosion potential to below $-0.350 \mathrm{~V}$ with respect to a copper-copper sulfate electrode (Ji et al. 2005; Darwin et al. 2009). Upon corrosion initiation, the specimens are washed and sampled for chlorides at the depth of the reinforcing steel. Samples are taken from the side of the specimen using a $6.4 \mathrm{~mm}(0.25 \mathrm{in}$.) masonry drill bit aligned so that the top of the bit is level with the top of the top mat of the reinforcing bar, as shown in Fig. 3. Ten samples, spaced $25 \mathrm{~mm}$ (1 in.) apart, are taken from each side of the specimen for a total of 20 samples. At each sample site, the hole is initially drilled to a depth of $13 \mathrm{~mm}(0.5 \mathrm{in}$.). The bit is then removed and rinsed with deionized water; the powdered concrete is discarded. The bit is reinserted and the hole is drilled to a depth of $89 \mathrm{~mm}$ (3.5 in.). The powdered concrete sample is collected and transferred to a plastic bag and labeled for analysis. Concrete samples are analyzed for water-soluble chloride content using Procedure A from AASHTO T 260-94 (1994).

\section{Pore solution analysis}

Specimens-The pore solution analysis specimens are $95 \mathrm{~mm}$ (3.75 in.) long cylinders with a diameter of $41 \mathrm{~mm}$ (1.61 in.). The mixture proportions used for the 


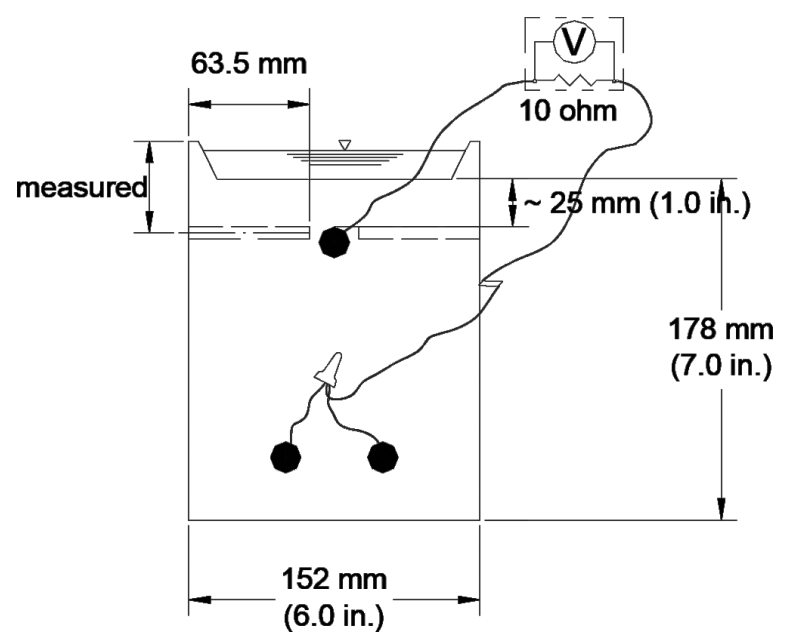

Fig. 3-Corrosion initiation specimen with chloride sampling sites marked. (Note: $1 \mathrm{~mm}=0.0394 \mathrm{in}$.)

Table 3-Mixture proportions for pore press specimens

\begin{tabular}{c|c|c|c|c}
\hline Mixture & $\begin{array}{c}\text { Water, kg } \\
(\mathrm{lb})\end{array}$ & $\begin{array}{c}\text { Cement, kg } \\
(\mathrm{lb})\end{array}$ & $\begin{array}{c}\text { Inhibitor, } \mathrm{mL} \\
(\mathrm{oz})\end{array}$ & $\begin{array}{c}\text { Inhibitor }^{*}, \mathrm{~L} / \mathrm{m}^{3} \\
\left(\mathrm{gal.}^{3} \mathrm{yd}^{3}\right)\end{array}$ \\
\hline Control & $0.409(0.90)$ & $0.909(2.0)$ & - & - \\
\hline $\mathrm{CN}$ & $0.373(0.82)$ & $0.909(2.0)$ & $38.4(1.30)$ & $15(3.03)$ \\
\hline AS & $0.395(0.87)$ & $0.909(2.0)$ & $12.8(0.43)$ & $5(1.01)$ \\
\hline ASSA & $0.386(0.85)$ & $0.909(2.0)$ & $21.6(0.73)$ & $7.6(1.54)$ \\
\hline
\end{tabular}

Equivalent dosage for concrete with cement content of $355 \mathrm{~kg} / \mathrm{m}^{3}\left(598 \mathrm{lb} / \mathrm{yd}^{3}\right)$ and $w / c$ is 0.45 .

Table 4-Test program

\begin{tabular}{c|c|c|c|c}
\hline \multirow{2}{*}{ Specimen } & \multicolumn{4}{|c}{ Test } \\
\cline { 2 - 5 } & $\begin{array}{c}\text { Southern } \\
\text { exposure }\end{array}$ & $\begin{array}{c}\text { Cracked } \\
\text { beam }\end{array}$ & $\begin{array}{c}\text { Corrosion } \\
\text { initiation }\end{array}$ & Pore press \\
\hline Control & 3 & 3 & 6 & 3 \\
\hline $\mathrm{CN}$ & 3 & 3 & 6 & 3 \\
\hline $\mathrm{AE}$ & 3 & 3 & 6 & 3 \\
\hline $\mathrm{ASSA}$ & 3 & 3 & 6 & 3 \\
\hline
\end{tabular}

Table 5-Water-soluble critical chloride corrosion thresholds (CCCTs) for conventional reinforcement without and with corrosion inhibitors

\begin{tabular}{c|c|c|c}
\hline Specimen & $\begin{array}{c}\text { Initiation age, } \\
\text { weeks }\end{array}$ & $\begin{array}{c}\text { Average chloride content, } \\
\mathrm{kg} / \mathrm{m}^{3}\left(\mathrm{lb} / \mathrm{yd}^{3}\right)\end{array}$ & $\begin{array}{c}\text { Coefficient of } \\
\text { variation }\end{array}$ \\
\hline Control & 14.2 & $0.96(1.61)$ & 0.38 \\
\hline $\mathrm{CN}$ & 26.5 & $1.59(2.67)$ & 0.27 \\
\hline $\mathrm{AE}$ & 19.5 & $1.23(2.07)$ & 0.47 \\
\hline $\mathrm{ASSA}$ & 28.5 & $0.43(0.72)$ & 0.55 \\
\hline
\end{tabular}

specimens are shown in Table 3 . The $w / c$ for all mixtures is 0.45 . The ratio of inhibitor to cement content is equivalent to the manufacturer's recommended dosage for concrete containing $355 \mathrm{~kg} / \mathrm{m}^{3}\left(598 \mathrm{lb} / \mathrm{yd}^{3}\right)$ of cement, which is the cement content of the mixtures used in the corrosion rate and chloride threshold specimens.
Test procedure and measurements-The specimens are tested 1 and 7 days after casting. The volume of extractable pore solution decreases with time, making extraction at later ages impractical. The pore press pressure vessel used in this study is based on a design by Barneyback and Diamond (1981). Pressure within the vessel is increased to $550 \mathrm{MPa}$ $(80,000 \mathrm{psi})$ over a 3 -minute period and held at $550 \mathrm{MPa}$ $(80,000 \mathrm{psi})$ for an additional 3 minutes using a computercontrolled testing machine with a capacity of $2670 \mathrm{kN}$ $(600,000 \mathrm{lbf})$. A glass container with a capacity of $50 \mathrm{~mL}$ $(1.7 \mathrm{fl.} \mathrm{oz})$ is used to collect the pore solution.

The volume of pore solution is measured and recorded. To provide enough volume of sample for analysis, samples are diluted to one-tenth of their original concentration using reverse-osmosis filtered water. All results are presented in terms of the undiluted sample. Immediately after expression of the pore solution, the $\mathrm{pH}$ of the pore solution is determined using hydrochloric acid titration, adjusting for the activity of the $\mathrm{OH}^{-}$ion. The concentration of fluoride, chloride, sulfate, nitrite, nitrate, and phosphate ions is then determined using ion chromatography.

\section{Test program}

The test program, consisting of three southern exposure, cracked beam, and pore solution tests and six corrosion initiation tests for each mixture, is summarized in Table 4. $\mathrm{pH}$ measurements were performed on all three series of pore solution specimens; ion chromatography was performed on pore solution Series 2 and 3 only.

\section{Compressive strength}

\section{RESULTS}

The average 28-day compressive strength of the control mixture and the mixtures containing corrosion inhibitors are listed in Table 2. The control mixture had an average 28-day compressive strength of $35.8 \mathrm{MPa}$ (5190 psi). The concrete containing $\mathrm{CN}$ exhibited a $12 \%$ increase in compressive strength compared to the control mixture, with an average compressive strength of $40.0 \mathrm{MPa}(5800 \mathrm{psi})$, while the concrete containing the AE exhibited a $15 \%$ decrease in compressive strength, with an average compressive strength of $30.4 \mathrm{MPa}$ (4410 psi). The addition of ASSA to the concrete resulted in an even greater decrease in compressive strength, with an average 28-day compressive strength of just $14.2 \mathrm{MPa}(2060 \mathrm{psi}), 60 \%$ below in strength of the control mixture.

\section{Corrosion initiation}

The average CCCTs for conventional reinforcement in concrete without and with inhibitors are shown in Table 5. Conventional reinforcement with no inhibitor had a CCCT of $0.96 \mathrm{~kg} / \mathrm{m}^{3}\left(1.61 \mathrm{lb} / \mathrm{yd}^{3}\right)$ and an average initiation time of 14.2 weeks. The use of corrosion inhibitors extended the time to initiation, with average times to initiation of 19.5 , 26.5, and 28.5 weeks for concrete containing $\mathrm{AE}, \mathrm{CN}$, and ASSA, respectively. The bars in concrete containing AE and $\mathrm{CN}$ also exhibited greater CCCT values than conventional reinforcement with no inhibitor, with values of 1.23 and $1.59 \mathrm{~kg} / \mathrm{m}^{3}\left(2.07\right.$ and $\left.2.67 \mathrm{lb} / \mathrm{yd}^{3}\right)$, respectively. The specimens containing ASSA, however, exhibited a significantly lower CCCT, with an average value of $0.43 \mathrm{~kg} / \mathrm{m}^{3}$ $\left(0.72 \mathrm{lb} / \mathrm{yd}^{3}\right)$. 


\section{Corrosion rate and loss}

The average corrosion (metal) losses for the southern exposure specimens without and with corrosion inhibitors are shown in Fig. 4 and listed in Table 6. Also listed in Table 6 are the coefficients of variation and average corrosion rates based on the slope of the corrosion loss plots for the individual specimens after initiation of corrosion (Darwin et al. 2011). Table 7 lists the ages at initiation. In the southern exposure specimens, conventional reinforcement with no inhibitor was the first to initiate corrosion (at 20.7 weeks) and exhibited the greatest average corrosion rate $(10.1 \mu \mathrm{m} / \mathrm{yr}$ [0.40 mils/yr] $)$ and loss $(14.4 \mu \mathrm{m}$ [0.57 mils]) at 96 weeks. To provide some context, a corrosion loss of approximately $25 \mu \mathrm{m}$ (1 mil) will cause cracking in concrete in cases where there is approximately $25 \mathrm{~mm}$ ( $1 \mathrm{in}$.) of cover over an uncoated reinforcing bar; the loss increases to a little more than $50 \mu \mathrm{m}(2$ mils $)$ for bars with a cover of approximately $75 \mathrm{~mm}$ (3 in.), which is typical of the top cover in bridge decks in many U.S. states (O'Reilly et al. 2011; Darwin et al. 2011).

All of the inhibitors tested increased the time to corrosion initiation; concrete containing CN and ASSA increased the time to initiation to 29.3 and 31.3 weeks, respectively, while specimens with $\mathrm{AE}$ had the longest time to corrosion initiation-37.3 weeks - which is significantly higher than observed in the corrosion initiation tests. All of the inhibitors tested also decreased the corrosion rate in uncracked concrete; reinforcement in concrete containing $\mathrm{CN}$ and $\mathrm{AE}$ had average corrosion rates of 6.67 and $2.91 \mu \mathrm{m} / \mathrm{yr}$ (0.26 and $0.11 \mathrm{mils} / \mathrm{yr}$ ), while reinforcement in specimens containing ASSA exhibited the lowest average corrosion rate $-1.25 \mu \mathrm{m} / \mathrm{yr}$ (0.05 mils/yr).

The average corrosion losses for the cracked beam specimens without and with corrosion inhibitors are shown in Fig. 5. Table 8 lists individual losses at 96 weeks, as well as the average losses and coefficients of variation for the cracked beam specimens. Corrosion initiated in all specimens during the first week of the test. The average corrosion rates through 96 weeks are also listed in Table 8 . Conventional reinforcement with no inhibitor exhibited the greatest average corrosion rate- $16.3 \mu \mathrm{m} / \mathrm{yr}$ (0.64 mils/yr). Although the inhibitors reduced the corrosion rate in cracked concrete compared to that observed for conventional steel without a corrosion inhibitor, they were not as effective as in uncracked concrete. The specimens containing $\mathrm{AE}$ and $\mathrm{CN}$ exhibited average corrosion rates of 11.9 and $14.5 \mu \mathrm{m} /$ yr (0.47 and $0.57 \mathrm{mils} / \mathrm{yr})$, respectively, while the specimens with concrete containing ASSA exhibited an average rate of $4.17 \mu \mathrm{m} / \mathrm{yr}(0.16 \mathrm{mils} / \mathrm{yr})$. As shown in Fig. 4 and 5, the order of the corrosion losses, from high to low, is the same for the southern exposure and cracked beam specimens.

\section{Pore solution analysis}

The average volumes of liquid collected from the specimens in pore solution Series 2 and 3 are presented in Table 9. On average, the specimens with no inhibitor tested 1 day after casting produced slightly more pore solution than those containing a corrosion inhibitor. No significant difference in volume of pore solution was observed for the specimens tested 7 days after casting.

The average $\mathrm{pH}$ from the three series of cement pastes tested is shown in Fig. 6, with error bars indicating the range of values obtained. Cement paste with no inhibitor exhibited an average pore solution $\mathrm{pH}$ of 13.5 and 13.6 in pore solutions collected 1 and 7 days after casting, respectively. Specimens containing $\mathrm{CN}$ exhibited $\mathrm{pH}$ values significantly lower than the control specimens, with average values of pore solution $\mathrm{pH}$ of 13.1 and 13.3, respectively, 1 day and 7 days after casting. The cement paste containing $\mathrm{AE}$ exhibited slightly higher values of pore solution $\mathrm{pH}$ than the cement pastes with no inhibitor, with average values of 13.6 and 13.7 in pore solutions extracted 1 day and 7 days after casting. No significant difference in $\mathrm{pH}$ was observed for specimens containing ASSA compared to those with no inhibitor.

For all specimens, the $\mathrm{pH}$ values increased between 1 and 7 days. Similar results were obtained by $\mathrm{Li}$ et al. (1999) for pore solutions collected from concrete containing calcium nitrite and concrete without an inhibitor. Li et al. (1999) obtained pore solution by creating a recess in the concrete in which they placed deionized water and into which ions from the surrounding material could leach. In that earlier study, the $\mathrm{pH}$ values remained constant until Day 25, after which the $\mathrm{pH}$ values decreased slightly. As

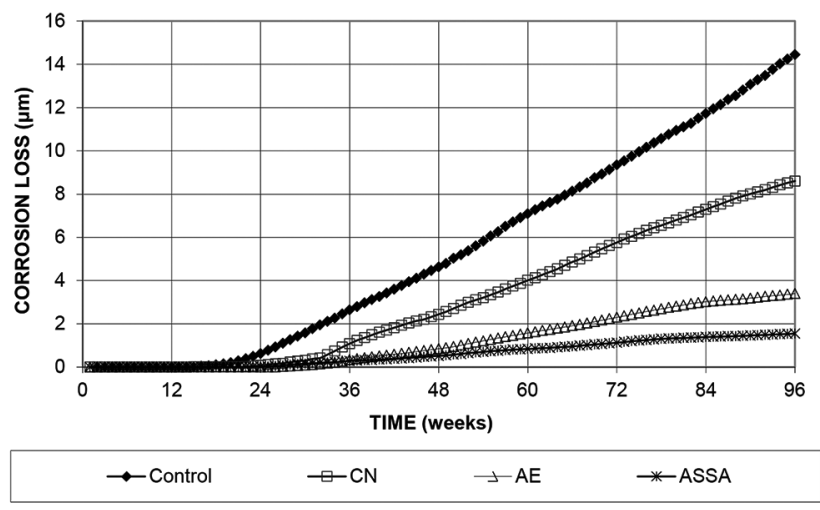

Fig. 4-Average corrosion loss for southern exposure specimens without and with corrosion inhibitors. (Note: $1 \mu \mathrm{m}=$ 0.0394 mils.)

Table 6-Corrosion loss and rate for southern exposure specimens through 96 weeks

\begin{tabular}{|c|c|c|c|c|c|c|c|c|c|c|}
\hline Specimen & \multicolumn{5}{|c|}{ Corrosion loss, $\mu \mathrm{m}$} & \multicolumn{5}{|c|}{ Average corrosion rate, $\mu \mathrm{m} / \mathrm{yr}^{*}$} \\
\hline Control & 14.3 & 13.8 & 15.2 & 14.4 & 0.051 & 10.7 & 9.7 & 10.0 & 10.1 & 0.048 \\
\hline $\mathrm{AE}$ & 3.11 & 2.29 & 4.79 & 3.40 & 0.375 & 2.57 & 2.60 & 3.56 & 2.91 & 0.194 \\
\hline ASSA & 1.24 & 1.59 & 1.82 & 1.55 & 0.188 & 0.791 & 1.03 & 1.92 & 1.25 & 0.477 \\
\hline
\end{tabular}

${ }^{*}$ After corrosion initiation.

Notes: $1 \mu \mathrm{m}=0.0394 \mathrm{mil} ; 1 \mu \mathrm{m} / \mathrm{yr}=0.0394 \mathrm{mil} / \mathrm{yr}$. 
observed in this study, Li et al. also observed a reduction in $\mathrm{pH}$ in specimens containing calcium nitrite compared to specimens without an inhibitor.

The average ion concentrations from the pore solutions are presented in Table 10. Concentrations of less than $10 \mathrm{ppm}$ (parts per million) correspond to a concentration of less than $1 \mathrm{ppm}$ in the diluted test sample. These concentrations are below the range of the standards used and are not considered significant.

Fluoride and chloride levels were low in all specimens. Moderate levels of nitrite were observed in the control specimens (no inhibitor) at 7 days, as well as specimens containing the organic inhibitors. As would be expected, the pore solutions from specimens containing $\mathrm{CN}$ showed high levels of nitrite for specimens tested both 1 and 7 days after casting. The concentration of nitrites in the samples containing $\mathrm{CN}$ exceeded the range of concentrations in the standards; the values presented were extrapolated from the calibration and are approximate.

For pore solutions collected 1 day after casting, the specimens containing $\mathrm{CN}$ exhibited a decreased sulfate ion concentration compared to control specimens. The specimens containing ASSA had an increased sulfate ion concentration (2318 ppm), with an average concentration nearly five times that of the control specimens (501 ppm). The sulfate level in specimens containing ASSA decreased somewhat in specimens tested 7 days after casting (1499 ppm) but remained significantly higher than that for the control

Table 7-Age at initiation for southern exposure specimens

\begin{tabular}{c|c|c|c|c|c}
\hline \multirow{2}{*}{ Specimen } & \multicolumn{5}{|c}{ Age at initiation, weeks } \\
\cline { 2 - 6 } & 1 & 2 & 3 & Average & Coefficient of variation \\
\hline Control & 23 & 23 & 16 & 20.7 & 0.196 \\
\hline $\mathrm{CN}$ & 33 & 22 & 33 & 29.3 & 0.217 \\
\hline $\mathrm{AE}$ & 34 & 51 & 27 & 37.3 & 0.331 \\
\hline ASSA & 45 & 26 & 23 & 31.3 & 0.381 \\
\hline
\end{tabular}

specimens (607 ppm). An analysis of the ASSA inhibitor alone indicated a low sulfate concentration ( $5 \mathrm{ppm})$, which is not enough to explain the high sulfate concentration in the

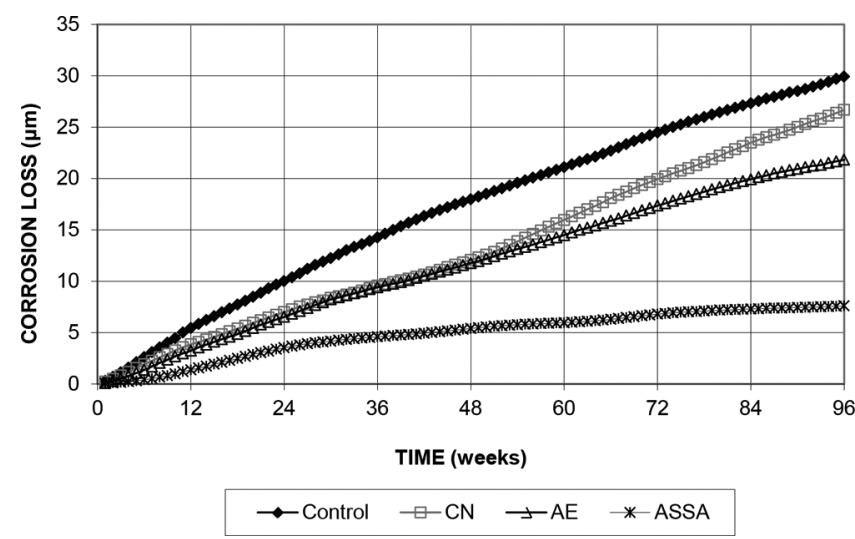

Fig. 5-Average corrosion loss for cracked beam specimens without and with corrosion inhibitors. (Note: $1 \mu \mathrm{m}=$ 0.0394 mils.)

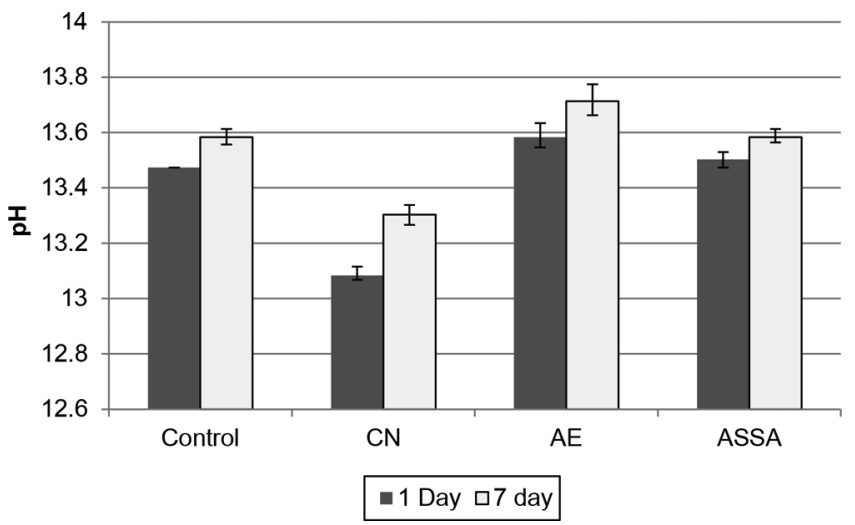

Fig. 6-Average pore solution $\mathrm{pH}$ for cement pastes. (Note: No variation observed in $\mathrm{pH}$ reading for control specimens at 1 day.)

Table 8-Corrosion loss and rate for cracked beam specimens through 96 weeks

\begin{tabular}{|c|c|c|c|c|c|c|c|c|c|c|}
\hline \multirow[b]{2}{*}{ Specimen } & \multicolumn{5}{|c|}{ Corrosion loss, $\mu \mathrm{m}$} & \multicolumn{5}{|c|}{ Average corrosion rate, $\mu \mathrm{m} / \mathrm{yr}^{*}$} \\
\hline & 1 & 2 & 3 & Average & Coefficient of variation & 1 & 2 & 3 & Average & Coefficient of variation \\
\hline Control & 44.4 & 22.7 & 22.6 & 29.9 & 0.419 & 24.6 & 12.2 & 12.1 & 16.3 & 0.439 \\
\hline $\mathrm{CN}$ & 32.1 & 26.4 & 21.6 & 26.7 & 0.198 & 17.48 & 14.4 & 11.6 & 14.5 & 0.204 \\
\hline $\mathrm{AE}$ & 24.6 & 18.3 & 22.6 & 21.8 & 0.148 & 13.64 & 9.80 & 12.4 & 11.9 & 0.164 \\
\hline ASSA & 8.64 & 6.31 & 7.84 & 7.60 & 0.155 & 4.92 & 3.44 & 4.16 & 4.17 & 0.176 \\
\hline
\end{tabular}

*After corrosion initiation.

Notes: $1 \mu \mathrm{m}=0.0394 \mathrm{mils} ; 1 \mu \mathrm{m} / \mathrm{yr}=0.0394 \mathrm{mils} / \mathrm{yr}$.

Table 9-Average volumes of liquid collected from specimens in pore solutions in Series 2 and 3

\begin{tabular}{|c|c|c|c|c|c|c|}
\hline \multirow[b]{3}{*}{ Specimen } & \multicolumn{4}{|c|}{ Average volume collected for each series, $\mathrm{mL}$} & & \\
\hline & \multicolumn{2}{|c|}{ Series 2} & \multicolumn{2}{|c|}{ Series 3} & \multicolumn{2}{|c|}{ Average volume, $\mathrm{mL}$} \\
\hline & 1 day & 7 days & 1 day & 7 days & 1 day & 7 days \\
\hline Control & 11.4 & 2.4 & 10.8 & 1.6 & 11.1 & 2.0 \\
\hline $\mathrm{CN}$ & 7.4 & 2.1 & 11.7 & 1.9 & 9.55 & 2.0 \\
\hline $\mathrm{AE}$ & 9.7 & 1.7 & 8.8 & 2.4 & 9.25 & 2.05 \\
\hline ASSA & 9.8 & 1.8 & 9.3 & 1.8 & 9.55 & 1.8 \\
\hline
\end{tabular}


pore solution. The specimens containing AE also exhibited increased sulfate levels at 7 days; however, sulfate levels at 1 day were only slightly higher than that of the control specimens. An analysis of AE also showed low sulfate levels ( $3 \mathrm{ppm})$. The analysis of the corrosion inhibitors is presented in Table 11.

Nitrate levels in all specimens were low with the exception of specimens containing $\mathrm{CN}$, which showed levels of approximately 800 ppm both 1 and 7 days after casting. This is likely due to the oxidation of some of the added nitrite.

No significant phosphate levels were detected in any of the pore solutions.

\section{DISCUSSION}

All three inhibitors tested in this study were effective in increasing the time to corrosion initiation and reducing the corrosion rate of reinforcing steel in uncracked concrete. The inhibitors, however, were significantly less effective in cracked concrete where the reinforcement in concrete containing $\mathrm{AE}$ or $\mathrm{CN}$ showed only slight reductions in corrosion rate compared to the bars in conventional concrete. Concrete containing ASSA was more effective at reducing corrosion rate overall, but still had lower effectiveness in cracked concrete. No inhibitor tested delayed the onset of corrosion in cracked concrete. In bridge decks, cracks develop directly over the reinforcement due to settlement and shrinkage. Thus, the behavior of the inhibitors in the cracked beam specimens is likely more indicative of their performance in structures such as bridge decks than is their behavior in southern exposure specimens.

Reductions in strength of 15 and $60 \%$ were observed with the use of AE and ASSA, respectively. The pore solution analysis of cement pastes containing these inhibitors showed that the use of AE resulted in elevated sulfate concentrations in pore solutions at 7 days, and the use of ASSA resulted in elevated sulfate levels at both 1 and 7 days. The elevated sulfate levels may be due to a change in the hydration process caused by the use of these inhibitors that ultimately impacts compressive strength, perhaps in a way similar to that caused by sulfate attack (Mindess et al. 2003). One positive difference compared to sulfate attack, however, is that the source of sulfates is limited and the concentration should decrease over time as the sulfates react with the other constituents of cement paste.

The critical chloride corrosion threshold of conventional steel is increased by the use of $\mathrm{AE}$ and $\mathrm{CN}$; however, the use of ASSA significantly lowers the CCCT of steel. This again may be due to the presence of sulfates, which not only have been shown to reduce the time to corrosion initiation by working in tandem with chlorides to destabilize the passive layer on iron and steel (Rasheeduzzafar et al. 1994; Al-Amoudi 2007; Shi and Sun 2011), but which have been observed to alone depassivate steel (Somuah et al. 1991; Turkman and Gavgali 2003).

The CCCT values obtained for concrete containing CN and $\mathrm{AE}$ in this study are approximately $60 \%$ lower than those obtained in other studies (Ann and Buenfeld 2007; Ormellese et al. 2008; Ormellese et al. 2011). In this study, watersoluble chloride content was measured, whereas in other studies, acid-soluble chloride content was measured. Watersoluble chloride content was chosen, as any chlorides that bind to the cement matrix are insoluble in water and not free to attack the passive layer of reinforcement. In addition, the referenced studies obtained chloride samples directly above the reinforcement, whereas in this study, chlorides were sampled away from but at the same depth as the reinforcement. This will again result in a lower CCCT value, but is more representative of values that are obtained from bridge decks, where samples are obtained away from reinforcement, as opposed to at the bar surface.

\section{Table 10-Average ion concentration from specimens in pore solutions in Series 2 and 3}

\begin{tabular}{|c|c|c|c|c|c|c|c|}
\hline & & \multicolumn{6}{|c|}{ Ion concentration, $\mathrm{ppm}^{*}$} \\
\hline \multicolumn{2}{|c|}{ Specimen } & Fluoride & Chloride & Nitrite & Sulfate & Nitrate & Phosphate \\
\hline \multirow{3}{*}{1 day } & Control & 58 & 102 & 109 & 501 & 8 & 0 \\
\hline & $\mathrm{AE}$ & 27 & 37 & 204 & 771 & 8 & 3 \\
\hline & ASSA & 59 & 57 & 255 & 2318 & 5 & 3 \\
\hline \multirow{3}{*}{7 days } & $\mathrm{CN}$ & 38 & 57 & $10,762^{\dagger}$ & 674 & 828 & 0 \\
\hline & $\mathrm{AE}$ & 109 & 36 & 312 & 1752 & 17 & 6 \\
\hline & ASSA & 34 & 22 & 245 & 1499 & 25 & 3 \\
\hline
\end{tabular}

*Parts per million.

${ }^{\dagger}$ Extrapolated.

Table 11-Average ion concentration for corrosion inhibitors

\begin{tabular}{|c|c|c|c|c|c|c|}
\hline Inhibitor & \multicolumn{6}{|c|}{ Ion concentration, $\mathrm{ppm}^{*}$} \\
\hline $\mathrm{CN}$ & 17 & 0 & $49,089^{\dagger}$ & 11 & 0 & 0 \\
\hline $\mathrm{AE}$ & 47 & 0 & 29 & 3 & 0 & 0 \\
\hline ASSA & 8 & 0 & 64 & 5 & 6 & 0 \\
\hline
\end{tabular}

*Parts per million.

Extrapolated. 
ASSA did delay the onset of corrosion in uncracked concrete due to decreased permeability of the concrete.

\section{SUMMARY AND CONCLUSIONS}

The research presented in this paper examines the effectiveness of three corrosion inhibitors-calcium nitrite $(\mathrm{CN})$, a solution of amines and esters (AE), and an alkenylsubstituted succinic acid salt (ASSA) - in conjunction with conventional reinforcement cast in concrete with a $w / c$ of 0.45 . Corrosion rate and corrosion loss were measured for reinforcement in both uncracked and cracked concrete, and the critical chloride corrosion threshold (CCCT) was determined. A pore solution analysis of cement pastes containing inhibitors was also performed. Concrete compressive strength was measured.

The following conclusions are based on the data and analyses presented in this paper.

1. All three inhibitors increase the time to corrosion initiation and decrease the corrosion rate of conventional reinforcement in uncracked concrete. Of the three inhibitors, ASSA results in the greatest decrease in corrosion rate compared to conventional reinforcement in concrete without an inhibitor.

2. The three corrosion inhibitors are less effective in cracked concrete than in uncracked concrete, although some benefit is still observed. No inhibitor, however, delayed the corrosion initiation in cracked concrete.

3. AE and $\mathrm{CN}$ increase the CCCT of conventional reinforcement compared with that measured when no inhibitor is used. ASSA, however, results in a significantly lower CCCT than observed for steel in concrete with no inhibitor.

4. The 28-day compressive strength of concrete containing $\mathrm{CN}$ was $12 \%$ higher than it was for concrete without corrosion inhibitor, wheras the compressive strengths of concretes containing $\mathrm{AE}$ and ASSA were $15 \%$ and $60 \%$ lower, respectively.

5. Pore solution analyses of cement pastes containing ASSA showed elevated sulfate content at 1 and 7 days, which may explain the significant reductions in CCCT and strength observed for concrete containing ASSA.

6. Pore solution analyses of cement pastes containing AE showed elevated sulfate content at 7 days, which may explain the reduction in strength noted for concrete containing AE.

\section{ACKNOWLEDGMENTS}

Support for the research described in this paper was provided by the U.S. Department of Transportation Federal Highway Administration under Contract No. DTFH61-03-C-00131 and the Kansas Department of Transportation under Contract No. C1131 and C1281. Material support was provided by the Concrete Steel Reinforcing Institute, DuPont Powder Coatings, 3M Corporation, Valspar Corporation, BASF Construction Chemicals, Grace Construction Products, Hycrete Technologies, Western Coating, Inc., and LRM Industries.

\section{REFERENCES}

AASHTO T 260-94, 1994, "Standard Method of Test for Sampling and Testing for Chloride Ion in Concrete and Concrete Raw Materials," American Association of State Highway and Transportation Officials, Washington, DC, $5 \mathrm{pp}$

Al-Amoudi, O. S. B., 2007, "Protection of Reinforced Concrete Structures in Chloride-Sulfate Exposures," Report No. 279, Corrosion 2007, NACE, pp. 072791-0727916.

Ann, K., and Buenfeld, N., 2007, "The Effect of Calcium Nitrite on the Chloride-Induced Corrosion of Steel in Concrete," Magazine of Concrete Research, V. 59, No. 9, Nov., pp. 689-697.

ASTM A955/A955M-10a, 2010, "Standard Specification for Deformed and Plain Stainless-Steel Bars for Concrete Reinforcement," ASTM International, West Conshohocken, PA, 14 pp.
Barneyback, R., and Diamond, S., 1981, "Expression and Analysis of Pore Fluids from Hardened Cement Pastes and Mortars," Cement and Concrete Research, V. 11, No. 2, Mar., pp. 279-285.

Batis, G.; Pantazopoulou, P.; and Routoulas, A., 2003, "Corrosion Protection Investigation of Reinforcement by Inorganic Coating in the Presence of Alkanolamine-Based Inhibitor," Cement and Concrete Research, V. 25, No. 3, Apr., pp. 371-377.

Berke, N., and Rosenberg, A., 1989, "Technical Review of Calcium Nitrite Corrosion Inhibitors in Concrete," Transportation Research Record: Journal of the Transportation Research Board, No. 1211, pp. 18-27.

Bola, M., and Newtson, C., 2005, "Field Evaluation of Marine Structures Containing Calcium Nitrite," Journal of Performance of Constructed Facilities, V. 19, No. 1, Feb., pp. 28-35.

Civjan, S.; LaFave, J.; Lovett, D.; Sund, D.; and Trybulski, J., 2003 "Performance Evaluation and Economic Analysis of Combinations of Durability Enhancing Admixtures (Mineral and Chemical) in Structural Concrete for the Northeast U.S.A.," Report NETCR-36, New England Transportation Consortium, Storrs, CT, 165 pp.

Darwin, D.; Browning, J.; O’Reilly, M.; Xing, L.; and Ji, J., 2009, "Critical Chloride Corrosion Threshold of Galvanized Reinforcing Bars," ACI Materials Journal, V. 106, No. 2, Mar.-Apr., pp. 176-183.

Darwin, D.; Browning, J.; Lindquist, W.; McLeod, H. A. K.; Yuan, J.; Toledo, M.; and Reynolds, D., 2010, "Low-Cracking, High-Performance Concrete Bridge Decks-Case Studies Over the First 6 Years," Transportation Research Record: Journal of the Transportation Research Board, No. 2202, pp. 61-69.

Darwin, D.; Browning, J.; O'Reilly, M.; Locke, C. E.; and Virmani, Y. P., 2011, "Multiple Corrosion Protection Systems for Reinforced Concrete Bridge Components," Publication No. FHWA-HRT-11-060, Federal Highway Administration, McLean, VA, Nov., 255 pp.

Gong, L.; Darwin, D.; and Browning, J., 2006, "Evaluation of Multiple Corrosion Protection Systems and Stainless Steel Clad Reinforcement for Reinforced Concrete," SM Report 82, University of Kansas Center for Research, Lawrence, KS, 621 pp.

Goodwin, P.; Frantz, G.; and Stephens, J., 2000, "Protection of Reinforcement with Corrosion Inhibitors, Phase II," CDOT Report No. JHR 00-279, University of Connecticut, Storrs, CT, $137 \mathrm{pp}$.

Ji, J.; Darwin, D.; and Browning, J., 2005, "Corrosion Resistance of Duplex Stainless Steels and MMFX Microcomposite Steel for Reinforced Concrete Bridge Decks," SM Report No. 80, University of Kansas Center for Research, Lawrence, KS, Dec., 453 pp.

Koch, G.; Broongers, H.; Thompson, N.; Virmani, Y.; and Payer, J., 2002, "Corrosion Cost and Preventive Strategies in the United States," Publication No. FHWA-RD-01-156, Federal Highway Administration, McLean, VA, 773 pp.

Krauss, P. D., and Rogalla, E. A., 1996, "Transverse Cracking in Newly Constructed Bridge Decks," NCHRP Report 380, TRB, National Research Council, Washington, DC, $126 \mathrm{pp}$.

Li, L.; Sagues, A.; and Poor, N., 1999, "In Situ Leaching Investigation of $\mathrm{pH}$ and Nitrite Concentration in Concrete Pore Solution," Cement and Concrete Research, V. 29, pp. 315-321.

Manning,D.,1996, "CorrosionPerformance ofEpoxy-CoatedReinforcing Steel: North American Experience," Construction \& Building Materials, V. 10, No. 5, July, pp. 349-365.

McDonald, D. B.; Pfeifer, D. W.; and Sherman, M. R., 1998, "Corrosion Evaluation of Epoxy-Coated, Metallic Clad and Solid Metallic Reinforcing Bars in Concrete," Report No. FHWA-RD-98-153, Federal Highway Administration, Washington, DC, $137 \mathrm{pp}$

Mindess, S.; Young, J.; and Darwin, D., 2003, Concrete, second edition, Pearson Education, Inc., Upper Saddle River, NJ, 644 pp.

Nmai, C.; Farrington, S.; and Bobrowski, G., 1992, "Organic-Based Corrosion-Inhibiting Admixture for Reinforced Concrete," Concrete International, V. 14, No. 4, Apr., pp. 45-51.

O'Reilly, M.; Darwin, D.; Browning, J.; and Locke, C. E., 2011, "Performance of Multiple Corrosion Protection Systems for Reinforced Concrete Bridge Decks," SM Report No. 100, University of Kansas Center for Research, Lawrence, KS, Jan., 487 pp.

Ormellese, M.; Bolzoni, F.; Lazzari, L.; and Pedeferri, M., 2008, "Effect of Corrosion Inhibitors on the Initiation of Chloride-Induced Corrosion on Reinforced Concrete Structures," Materials and Corrosion, V. 59, No. 2, pp. 98-106.

Ormellese, M.; Bolzoni, F.; Lazzari, L.; Brenna, A.; and Pedeferri, M., 2011, "Organic Substances as Inhibitors for Chloride-Induced Corrosion in Reinforced Concrete," Materials and Corrosion, V. 62, No. 2, pp. 170-177.

Pyc, W.; Zemajtis, J.; Weyers, R.; and Sprinkel, M., 1999, "Evaluating Corrosion-Inhibiting Admixtures," Concrete International, V. 21, No. 4 , Apr., pp. 39-44. 
Rasheeduzzafar; A.-A.; Maslehuddin, M.; Al-Amoudi, O. S. B.; and Abduljauwad, S. N., 1994, "Influence of Sulfate Ions on Chloride-Induced Reinforcement Corrosion in Portland and Blended Cement Concretes," Cement, Concrete and Aggregates, V. 16, No. 1, June, pp. 3-11.

Rodriguez, O., and Hooton, D., 2003, "Influence of Cracks on Chloride Ingress into Concrete," ACI Materials Journal, V. 100, No. 2, Mar.-Apr., pp. 120-126.

Shi, J., and Sun, W., 2011, "Effect of Sulfate Ions on the Corrosion Behavior of Steel in Concrete Using Electrochemical Methods," Advanced Materials Research, V. 163-167, pp. 3049-3054.

Somuah, S.; Boah, J.; Leblanc, P.; Al-Tayyib, A.; and Al-Mana, A., 1991, "Effect of Sulfate and Carbonate Ions on Reinforcing Steel Corrosion as Evaluated Using AC Impedance Spectroscopy," ACI Materials Journal, V. 88, No. 1, Jan.-Feb., pp. 49-55.
Soylev, T. A., and Richardson, M. G., 2008, "Corrosion Inhibitors for Steel in Concrete: State-of-the-Art Report," Construction \& Building Materials, V. 22, No. 4, Apr., pp. 609-622.

Turkman, I., and Gavgali, M., 2003, "Influence of Mineral Admixtures on the Some Properties and Corrosion of Steel Embedded in Sodium Sulfate Solution of Concrete," Materials Letters, V. 57, No. 21, pp. 3222-3233.

Wojakowski, J., and Distlehorst, J., 2009, "Laboratory and Field Testing of Hycrete Corrosion-Inhibiting Admixture for Concrete," Proceedings of the 2009 Mid-Continent Transportation Research Symposium, Ames, IA, Aug., 15 pp.

Xing, L.; Darwin, D.; and Browning, J., 2010, "Evaluation of Multiple Corrosion Protection Systems and Corrosion Inhibitors for Reinforced Concrete Bridge Decks," SM Report 99, University of Kansas Center for Research, Lawrence, KS, 507 pp. 
